\title{
Genetic Divergence of Rice Genotypes Revealed by Bacterial Blight Disease and Morphological Traits
}

\author{
S A I Nihad ${ }^{1 *}$, A Ara ${ }^{1}$, M M Rashid ${ }^{1}$, M A I Hasan ${ }^{1}$, M A I Khan ${ }^{1}$, M A Latif ${ }^{1}$
}

\begin{abstract}
Bacterial blight is a perilous impediment for rice production. Resistant variety is a sustainable approach to fend off the loss of rice due to bacterial blight disease. In this study, 94 genotypes were screened against bacterial blight disease and its morphological diversity was assessed to find out the resistant donor with desirable morphological characters. Bacterial blight pathogen was inoculated following leaf clipping method for disease scoring. Out of 94 genotypes, 12 showed a resistant reaction, 13 showed moderately resistant reaction and 69 genotypes showed a susceptible reaction. Positive correlation was recorded between yield and most of the morphological characters. Yield hill $^{-1}$ was significantly correlated with the number of tiller hill-1 $\left(0.503^{* *}\right)$, number of effective tiller $\operatorname{hill}^{-1}\left(0.538^{* *}\right)$, total number of spikelets panicle ${ }^{-1}\left(0.595^{* *}\right)$, number of filled grain panicle ${ }^{-1}\left(0.595^{* *}\right)$, number of unfilled spikelet panicle ${ }^{-1}\left(0.239^{*}\right)$ and 1000 grain weight hill-1 $\left(0.843^{* *}\right)$. Eleven quantitative characters grouped 94 rice genotypes in 16 clusters at coefficient 3.38 and it indicated the presence of great amount diversity among the genotypes. Principal component analysis (PCA) supported the cluster analysis and the first four principal components explained around $70.99 \%$ of total divergence for all morphological characters. Principal coordinate analysis (PCoA) demonstrated that the genotypes BR8862-29-1-5-1-3, SVIN301, SVIN321, BR9207-45-2-2, SVIN018, 1RBB5, SVIN038, BRRI dhan 28 and BRRI dhan29 were placed in distant position from the centroid and it indicated that they were more diverse than the genotypes near the centroid. However, based on disease reaction and genetic diversity analysis crossing could be made between, resistant genotypes such as SVIN317, SVIN017, SVIN316, SVIN313, SVIN315, SVIN314, SVIN038, SVIN307, SVIN302, SVIN304 with the susceptible variety more specifically with BRRI dhan28, BRRI dhan29, BRRI dhan50, BRRI dhan58, BRRI dhan63, BRRI dhan74, BRRI dhan81 and BRRI dhan84 to develop bacterial blight resistant variety.
\end{abstract}

Key words: Bacterial blight, Correlation, Disease screening, Genetic divergence analysis, Morphological traits, Rice genotypes.

\section{INTRODUCTION}

Rice is the primary diet of around half of the Earth's people (Wennberg, 2014). Changing weather parameters of the climate are responsible for several biotic and abiotic stresses which become a threat to rice cultivation in the world (Juroszek and Von Tiedemann, 2011; Zayan, 2018). Rice is threatened by many diseases where bacterial blight is responsible for $20-30 \%$ yield loss $(\mathrm{Ou}$, 1985), and the severe attack may cause $80 \%$ (Singh et al., 1997) to $100 \%$ yield loss of rice (Zhai and Zhu, 1999). Bangladesh is an overpopulated country and it is not beyond the effect of climate change and emerging of several pests for crop production. Rice is also a fundamental foodstuff for the population of Bangladesh and here food security is equivalent to rice security (Kabir et al., 2015).
To date, 32 diseases have been identified in Bangladesh from here blast, tungro, bacterial leaf blight and sheath blight are the severe threats for rice production in Bangladesh (Latif et al., 2013). Xanthomonas oryzae pv oryzae is the causal organism of bacterial leaf blight disease. The occurrence of this disease was first reported in 1968 in Bangladesh. "Leaf blight" and "Kresek" are the two phases of this disease and the outbreak of these two phases may cause an epidemic in the rice production area (Reddy and Ou, 1976; Ou, 1985). Overdose of nitrogen fertilizer make the rice plant susceptible and favours the outbreak of the disease. Water soak lesion from the leaf margin followed by yellow to white stripes and pale yellow to necrotic symptoms on leaf blades at later stage are the identified symptoms of bacterial leaf blight disease 
(Mizukami and Wakimoto, 1969; Ou, 1985). The word "Kresek" is generated by the Vernacular word of Java, which means "the sound of dead leaves" stroked with one another (Wakimoto, 1969). Kresek was first identified in Indonesia during midcenturies and that time it was considered as a different rice disease but after consecutive studies, it was discovered that the disease kresek occurred by the same pathogen of bacterial leaf blight disease (Mizukami, 1956). The disease kresek generally appears after 1-2 weeks of transplanting and grayish green to whitish leaf blades along with sudden wilting of the plants are the identified symptoms of the kresek disease (Goto, 1992; Watanabe, 1975). Moreover, bacterial ooze in water and rotting smell from the roots are ideal symptoms for kresek disease identification.

As bacterial leaf blight is a bacterial disease, use of antibiotics is the prime solution to control it but due to policy regulation and environment concern adoption of antibiotics in Bangladesh is strictly prohibited. However, no chemicals except antibiotics are effective against bacterial disease. However, use of resistant variety is one and only economic and sustainable environment friendly strategy to tackle up the bacterial disease of rice (Khush et al., 1989; Islam et al., 2017). A resistant variety containing the resistant genes have been released to reduce the rice yield loss by bacterial blight disease (Chen et al., 2002). However, emerging of new races shorten the sustainability of resistant variety and so it is necessary to seek out for the new donors of resistance. To develop bacterial blight resistant high yielding variety there is no alternative of continuous searching of the resistant source to initiate a breeding programme (Islam et al., 2017). Moreover, variation among the parents are also a prime concern to find desirable progeny with superior characters.

Bacterial blight resistant advanced lines of International Rice Research Institute (IRRI) are being used as donor parents in several countries to develop resistant variety. In this study, 94 genotypes were tested against the bacterial blight isolate of Bangladesh to screen out the resistant and susceptible genotypes. Moreover, diversity analysis based on morphological characters were also measured to detect the variation among the genotypes.

\section{MATERIALS AND METHODS}

\section{Genotypes collection and plant generation}

A total of 94 genotypes were collected from IRRI, Los Banos, Philippines and Bangladesh Rice Research Institute (BRRI), Gazipur-1701, Bangladesh (Table 1). Plants were grownup in the experimental plot of Plant Pathology Division for bacterial blight screening. Genotypes were grown in the seedbed and 25 days aged plants were planted in the plot by implementing randomized complete block design (RCBD) with three replications.

\section{Isolation and purification of pathogens}

Bacterial blight infected plants were obtained from rice field for isolation of the pathogen. Infected leaves were cut into small pieces $(5 \mathrm{~mm}$ infected tissue and $5 \mathrm{~mm}$ of adjacent healthy tissue) and placed in $70 \%$ ethanol for 10 seconds, after that the leaves were washed through sterilized water and immersed in 300 $\mu 1$ sterilized water for 15 minutes. A loop was dipped into the water and streaked on PSA (peptone $1.2 \%$, sucrose $1.2 \%$, agar $2 \%$ ) plates followed by incubation for 3 to 4 days at $30^{\circ} \mathrm{C}$ for bacterial colony development. The yellow colonies were selected and purified on fresh PSA plates with a sterilized wire loop. The pathogenicity was confirmed according to Koch's postulates on a susceptible variety.

\section{Bacterial culture preparation and disease scoring}

After dilution of the bacterial inoculum by distilled water, the concentration was adjusted to $3.3 \times 10^{8}$ colony forming units per milliliter $(\mathrm{cfu} / \mathrm{mL})$, which is a suitable concentration for 
Xoo infection in the host. Bacterial culture suspension was inoculated in the plants by clipping methods. Studied genotypes were inoculated at the booting stage. The scissors were dipped in the inoculum and one-fourth of top 3- 4 leaves were clipped by the scissors. After 21 days of inoculation, disease severity and incidence were scored based on following IRRI Standard Evaluation System (IRRI-SES) (IRRI, 2013). Resistant, 1-5\% of diseased leaf area (Score 1), moderately resistant 6-12\% (Score 3), moderately susceptible 12-25\% (Score 5), susceptible 26-50\% (Score 7), highly susceptible $>50 \%$ (Score 9). Later, moderately susceptible, susceptible and highly susceptible were merged into one group as susceptible. However, other groups (resistant and moderately resistant) remain the same as before.

\section{Morphological characters}

Morphological characters such as plant height (PHT, cm), number of tillers per hill $\left(\mathrm{NTH}^{-1}\right.$, no), number of effective tiller per hill $\left(\mathrm{ETH}^{-1}\right.$, no), days to flowering (DF, no), days to maturity (DM, no), Panicle length (PL, cm), number of filled spikelet per panicle (NFSP-1, no), number of unfilled spikelet per panicle $\left(\mathrm{UFSP}^{-1}\right)$, total number of spikelets per panicle (TNSP-1), 1000 grain weight (TGW) and yield per hill measured from each replication plot of the respective genotypes.

\section{Data analysis}

Descriptive statistics of morphological parameters of the genotypes were calculated by Microsoft excel version 2016. To measure the associations among the 11 morphological characters Pearson's correlation coefficient was done by SPSS software version 20. Euclidean distance of the 94 genotypes was measured based on morphological data by using NTSYSpc version 2.1 (Rohlf, 1998). Moreover, unweighted pair group methods of arithmetic mean (UPGMA) algorithm and SAHN clustering were applied to determine the relationship among the genotypes. The principal component analysis (PCA) of studied rice lines were revealed by EIGEN and PROJ modules of NTSYS-pc. Moreover, the principal coordinate analysis was done by following the manual instruction of the same software.

\section{RESULTS AND DISCUSSION}

\section{Descriptive statistics of morphological parameters of the genotypes}

Ninety-four genotypes were screened and out of them 12 showed resistant reaction, 13 showed moderately resistant and 69 showed susceptible reaction against bacterial blight pathogen (Table 1). Table 2 shows the descriptive statistics of morphological parameters of the studied genotypes. Among all rice genotypes, the plant height ranged between 64.4 to $105.2 \mathrm{~cm}$ with an average of $81.95 \mathrm{~cm}$. The highest $(105.2 \mathrm{~cm})$ value for plant height was observed in BR9207-45-2-2 and the lowest (64.4) plant height were observed in genotypes SVIN037 and 1RBB8. Besides, number of tiller/hill was ranged from 11 to 33 including an average of 22.87. The maximum and minimum number of tillers belonged to genotypes SVIN311 and BRRI dhan29-SC3-28-16-10-6-HR6 (com)-HR1(GAZ)$\mathrm{P} 11(\mathrm{Hbj})$ respectively. The number of effective tillers hill-1 varied between 8 to 32 with an average of 20.96. The highest number of effective tillers hill-1 ${ }^{-1}$ was obtained in BRRI dhan74. The lowest number of that tillers was found in BRRI dhan29-SC3-28-16-10-6-HR6 (com)-HR1(GAZ)-P11(Hbj) and BR8862-29-1-51-3. Days to flowering varied from 103 to 118 days with an average of 110.43 days. In case of days to maturity, the value was ranged from 133 to 148 with a mean value of 140.43 . The line SVIN039 showed the highest panicle length $(29.4 \mathrm{~cm})$ and BR8862-8-3-4-4-1 showed the lowest panicle length $(17.6 \mathrm{~cm})$, whereas the average panicle length was $23.94 \mathrm{~cm}$. The highest (141) number of spikelets panicle ${ }^{-1}$ was recorded in genotype SVIN301 while that of 
the lowest (54) was recorded in genotype IRBB10. The average number of spikelet panicle $^{-1}$ was 87.48. The range of filled grains panicle $\mathrm{e}^{-1}$ was 45 to 106 with an average value of 67.24. The highest (106) filled grain was found in BR8862-29-1-5-1-3 and that of the lowest (45) was recorded in IR99285-1-1-1-P1. The maximum (40) number of unfilled grains was recorded IR99285-1-1-1-P2 and that of the lowest (4) number was found in BRRI dhan63 with an average value of 18.24 . The range of 1000 -seed weight was 13 to $28 \mathrm{~g}$ with an average value of $21.69 \mathrm{~g}$. The minimum value for TGW was observed in SVIN304 and the highest value was found in BR8862-8-3-4-4-1. Whereas the grain yield hill-1 ranged from 12.56 to $80.80 \mathrm{~g}$ with the average value of 30.74 g. The maximum yield per hill was recorded in BR9207-45-2-2 and that of the lowest was found in SVIN020.

Table 1. List of 94 genotypes and their reactions to bacterial blight disease.

\begin{tabular}{|c|c|c|c|c|c|c|c|c|}
\hline Designation & Code & DR & Designation & Code & DR & Designation & Code & DR \\
\hline SVIN317 & G1 & $\mathrm{R}$ & SVIN308 & G33 & $S$ & IRBB64 & G65 & S \\
\hline SVIN017 & G2 & $\mathrm{R}$ & SVIN296 & G34 & $S$ & 1RBB8 & G66 & S \\
\hline SVIN316 & G3 & $\mathrm{R}$ & SVIN010 & G35 & S & Purbachi & G67 & S \\
\hline SVIN313 & G4 & $\mathrm{R}$ & SVIN035 & G36 & $S$ & IR99056-B-B-15 & G68 & S \\
\hline SVIN315 & G5 & $\mathrm{R}$ & SVIN012 & G37 & S & BR-8938-30-2-4-2-1 & G69 & S \\
\hline SVIN314 & G6 & $\mathrm{R}$ & SVIN045 & G38 & S & BR8904-28-1-2-2-2 & G70 & S \\
\hline SVIN038 & G7 & $\mathrm{R}$ & SVIN301 & G39 & $S$ & KARJAT-5 & G71 & S \\
\hline SVIN307 & G8 & $\mathrm{R}$ & SVIN050 & G40 & S & BR9675-68-5-1 & G72 & S \\
\hline SVIN302 & G9 & $\mathrm{R}$ & SVIN287 & G41 & $S$ & BR8562-11-2-6-1-1-1 & G73 & S \\
\hline SVIN304 & G10 & $\mathrm{R}$ & SVIN037 & G42 & S & $\begin{array}{l}\text { BRRI dhan29-SC3-28-16-10-6- } \\
\text { HR6(com)-HR1(GAZ)-P8(Hbj) }\end{array}$ & G74 & S \\
\hline SVIN291 & G11 & MR & SVIN306 & G43 & S & $\begin{array}{l}\text { BRRI dhan29-SC3-28-16-10-6- } \\
\text { HR6(com)-HR1(GAZ)-P11(Hbj) }\end{array}$ & G75 & S \\
\hline SVIN017 & G12 & MR & SVIN029 & G44 & S & BR8862-29-1-5-1-3 & G76 & S \\
\hline SVIN046 & G13 & MR & SVIN296 & G45 & $S$ & BR8862-8-3-4-4-1 & G77 & S \\
\hline SVIN045 & G14 & MR & SVIN003 & G46 & S & BR8995-2-5-5-2-1 & G78 & S \\
\hline SVIN305 & G15 & MR & SVIN020 & G47 & S & BR9205-10-1-5-3 & G79 & S \\
\hline SVIN039 & G16 & MR & SVIN001 & G48 & S & BR8590-5-2-5-2-1 & G80 & S \\
\hline SVIN018 & G17 & MR & SVIN041 & G49 & S & BR8590-5-2-5-2-2 & G81 & S \\
\hline SVIN312 & G18 & MR & SVIN321 & G50 & $S$ & BR9207-45-2-2 & G82 & S \\
\hline SVIN318 & G19 & MR & SVIN024 & G51 & S & IR99285-1-1-1-P2 & G83 & S \\
\hline SVIN046 & G20 & MR & SVIN047 & G52 & S & BR(Bio) 9777-26-4-3 & G84 & S \\
\hline SVIN311 & G21 & MR & SVIN299 & G53 & $S$ & BRRI dhan28 & G85 & S \\
\hline 1RBB27 & G22 & MR & SVIN026 & G54 & S & BRRI dhan29 & G86 & S \\
\hline $\begin{array}{l}\text { IR99285-1-1- } \\
\text { 1-P1 }\end{array}$ & G23 & MR & SVIN306 & G55 & S & BRRI dhan50 & G87 & S \\
\hline
\end{tabular}


Table 1. Continued.

\begin{tabular}{lllllllll}
\hline Designation & Code & DR & Designation & Code & DR & Designation & Code & DR \\
\hline SVIN301 & G24 & S & SVIN038 & G56 & S & BRRI dhan58 & G88 & S \\
SVIN048 & G25 & S & 1RBB10 & G57 & S & BRRI dhan63 & G89 & S \\
SVIN020 & G26 & S & 1RBB11 & G58 & S & BRRI dhan74 & G90 & S \\
SVIN008 & G27 & S & 1RBB13 & G59 & S & BRRI dhan81 & G91 & S \\
SVIN040 & G28 & S & 1RBB2 & G60 & S & BRRI dhan84 & G92 & S \\
SVIN001 & G29 & S & 1RBB24 & G61 & S & IRBB60 & G93 & R \\
SVIN319 & G30 & S & 1RBB3 & G62 & S & IRBB65 & G94 & R \\
SVIN033 & G31 & S & 1RBB4 & G63 & S & & & \\
SVIN298 & G32 & S & 1RBB5 & G64 & S & & & \\
\hline
\end{tabular}

Note: DR-Disease reaction, R-Resistant, MR-Moderately resistant, S-Susceptible.

Table 2. Descriptive statistics of 11 traits of 94 rice genotypes.

\begin{tabular}{cccccccccccc}
\hline & PHT & NTH $^{-1}$ & ETH $^{-1}$ & DF & DM & PL & NSP-1 & FGP-1 & UFGP-1 & TGW & YH $^{-1}$ \\
\hline Max & 105.2 & 33 & 32 & 118 & 148 & 29.4 & 141 & 106 & 40 & 28 & 80.80 \\
Min & 64.4 & 11 & 8 & 103 & 133 & 17.6 & 54 & 45 & 4 & 13 & 12.56 \\
Mean & 81.95 & 22.87 & 20.96 & 110.44 & 140.44 & 23.94 & 87.00 & 67.24 & 18.24 & 21.69 & 30.74 \\
\hline CV $(\%)$ & 12.35 & 23.74 & 25.81 & 5.30 & 4.17 & 10.09 & 23.31 & 21.41 & 44.37 & 13.87 & 40.57 \\
\hline
\end{tabular}

Note: PHT-Plant height, NTH-1 - Number of tiller per hill, ETH ${ }^{-1}$ - Effective tiller per hill, DF-Days to flowering, DM- Days to maturity, PL-Panicle length, TNSP-1_Total number of spikelet per panicle, FSP-1-Number of filled spikelet per panicle, UFSP-1-Number of unfilled spikelet per panicle, TGW-1000 grain weight, $\mathrm{YH}^{-1}$-Yield per hill.

\section{Correlation study of morphological characters}

Pearson's correlation coefficient was measured from the data of 11 morphological characters of 94 rice genotypes (Table 3). Maximum traits showed a positive relationship after correlation analysis. Total number of spikelets panicle $^{-1}$ displayed significant $(p \quad \leq 0.01)$ positive relationship with the number of filled grain panicle ${ }^{-1}\left(0.895^{* *}\right)$, number of unfilled grain panicle ${ }^{-1}\left(0.593^{* *}\right)$, TGW $\left(0.389^{* *}\right)$ and Yield hill ${ }^{-1}\left(0.595^{* *}\right)$. Yield hill-1 had highly significant and positive correlation with the number of tiller hill $\left(0.503^{* *}\right)$, number of effective tiller hill ${ }^{-1}\left(0.538^{* *}\right)$, total number of spikelets panicle ${ }^{-1}\left(0.595^{* *}\right)$, number of filled grain panicle ${ }^{-1}\left(0.595^{* *}\right)$, number of unfilled spikelet panicle ${ }^{-1}\left(0.239^{*}\right)$ and TGW hill-1 $\left(0.843^{* *}\right)$. Many rice scientists reported that the relationship between grain yield and TGW is highly significant (Mazid et al., 2013; Xu et al.,
2015; Li et al., 2019). Morphological traits are highly influenced by environmental conditions so it is better to select highly correlated traits for the breeding programme.

\section{Cluster analysis}

Eleven morphological characters grouped the studied genotypes in sixteen principal groups at coefficient 3.38 and it indicated the presence of diversity among the genotypes. Based on 18 quantitative characters, 58 rice genotypes were clustered into four groups (Ahmadikhah et al., 2008) whereas Mazid et al., 2013 stated six groups in terms of 13 morphological characters of 41 accession of rice. Melchinger (1993) suggested that multivariate statistical techniques i.e. cluster and PCA could be applied to study the variation among the samples perfectly. Table 4 depicted that Cluster 2 was the largest (containing 24 genotypes) followed by Cluster-6 (21 genotypes), 
Table 3. Correlation studies of $\mathbf{1 1}$ morphological characters of $\mathbf{9 4}$ rice genotypes.

\begin{tabular}{|c|c|c|c|c|c|c|c|c|c|c|c|}
\hline Traits & PHT & NTH-1 & ETH-1 $^{1}$ & $\mathrm{DF}$ & $\mathrm{DM}$ & PL & $\mathrm{NSP}^{-1}$ & FGP $^{-1}$ & UFGP-1 $^{-1}$ & $\begin{array}{l}1000 \\
\text { GW }\end{array}$ & $\mathrm{YH}^{-1}$ \\
\hline PH & 1 & & & & & & & & & & \\
\hline NTH $^{-1}$ & -0.029 & 1 & & & & & & & & & \\
\hline ETH $^{-1}$ & -0.017 & $0.953^{* *}$ & 1 & & & & & & & & \\
\hline DF & 0.123 & 0.070 & 0.081 & 1 & & & & & & & \\
\hline DM & 0.123 & 0.070 & 0.081 & $1.000^{* *}$ & 1 & & & & & & \\
\hline PL & -0.157 & -0.124 & -0.230 & 0.040 & 0.040 & 1 & & & & & \\
\hline NGP-1 & -0.181 & 0.025 & 0.017 & 0.052 & 0.052 & 0.0880 & 1 & & & & \\
\hline FGP $^{-1}$ & -0.128 & 0.003 & -0.003 & 0.11 & 0.110 & 0.1160 & $0.895^{* *}$ & 1 & & & \\
\hline UFGP-1 & -0.169 & 0.051 & 0.043 & -0.084 & -0.084 & -0.0150 & $0.593^{* *}$ & 0.172 & 1 & & \\
\hline $\begin{array}{l}1000 \\
\text { GW }\end{array}$ & -0.130 & 0.171 & $0.209^{*}$ & 0.143 & 0.143 & -0.1900 & $0.389^{* *}$ & $0.372^{\text {** }}$ & 0.187 & 1 & \\
\hline $\mathbf{Y H}^{-1}$ & -0.114 & $0.503^{* *}$ & $0.538^{* *}$ & 0.117 & 0.117 & -0.1720 & $0.595^{* *}$ & $0.595^{* *}$ & $0.239^{*}$ & $0.843^{* *}$ & 1 \\
\hline
\end{tabular}

Note: PHT-Plant height, $\mathrm{NTH}^{-1}$ - Number of tiller per hill, $\mathrm{ETH}^{-1}$ - Effective tiller per hill, DF-Days to flowering, DM- Days to maturity, PL-Panicle length, TNSP-1-Total number of spikelet per panicle, FSP-1_Number of filled spikelet per panicle, UFSP-1-Number of unfilled spikelet per panicle, TGW-1000 grain weight, $\mathrm{YH}^{-1}-$ Yield per hill.

${ }^{* *}$ indicates significant at the 0.01 level, " indicates significant at the 0.05 level.

Cluster-5 (9 genotypes), Cluster-4 (8 genotypes), Cluster-1 (7 genotypes), Cluster8 (5 genotypes), Cluster-7 (4 genotypes), Cluster-3 and Cluster-10 (3 genotypes each), Cluster-9, Cluster-11 and Cluster-12 (2 genotypes per cluster) and Cluster-13, Cluster-14, Cluster-15, and Cluster-16 (each contains a single genotype). Moreover, genotypes having resistant, moderately resistant and susceptible phenomena were placed in the same cluster and this happened because they might be originated from the same ancestors having similar morphological characters. The cluster-14 had the highest average value for the three characters (Table 5) those are plant height $(102.67 \mathrm{~cm})$, days to flowering (118) and days to maturity (148). Cluster-16 contained the maximum number spikelets per panicle (132) and filled grain per panicle (106). The highest (32.63) average number of tiller was found in cluster-7 while the highest (30.33) number of effective tiller per hill was found in cluster-3. The highest mean panicle length $(27.20 \mathrm{~cm})$ and yield per hill $(61.51 \mathrm{~g})$ were found in cluster-13 whereas the maximum mean value $(29 \mathrm{~g})$ for TGW was found in cluster-12. On the contrary, cluster-16, showed the lowest mean value for number of tiller hill-1 (14.33), number of effective tiller per hill (8.67), TGW $(18.00 \mathrm{~g})$ and yield per hill (16.54 g). Average lowest value for number of tiller per hill (14.33), number of effective tiller per hill (12.83) and TGW (19.50 g) were found in cluster-9. Moreover, the lowest value for plant height (69.50), days to flowering (105.05), days to maturity (134.25), panicle length $(22.48 \mathrm{~cm})$ and yield per hill (19.10) was found in cluster-11, cluster-6, clster-4, cluster-8 and cluster-5, respectively. 
Table 4. Cluster wise distribution of genotypes.

\begin{tabular}{|c|c|c|c|}
\hline Cluster & $\begin{array}{l}\text { No. of } \\
\text { genotype }\end{array}$ & Genotype & Reaction \\
\hline Cluster-1 & 7 & SVIN317, SVIN315, SVIN291, SVIN305, SVIN039, SVIN046, IR99285-1-1-1-P1 & $\mathrm{R}+\mathrm{MR}$ \\
\hline Cluster-2 & 24 & $\begin{array}{l}\text { SVIN048, SVIN008, SVIN001, SVIN319, SVIN035, SVIN012, SVIN287, SVIN003, } \\
\text { lRBB11, IRBB13, IRBB4, Purbachi, BR8904-28-1-2-2-2, BR9675-68-5-1, BR8562-11- } \\
\text { 2-6-1-1-1, BR8862-8-3-4-4-1, BR9205-10-1-5-3, BR8590-5-2-5-2-1, BR8590-5-2-5-2- } \\
\text { 2, BRRI dhan58, BRRI dhan81, BRRI dhan84, IRBB60, IRBB65. }\end{array}$ & $\mathrm{S}+\mathrm{R}$ \\
\hline Cluster-3 & 3 & 1RBB27, 1RBB8, BRRI dhan74 & $\mathrm{MR}+\mathrm{S}$ \\
\hline Cluster-4 & 8 & SVIN313, SVIN314, SVIN038, SVIN302, SVIN304, SVIN017, SVIN045, SVIN312 & $\mathrm{R}+\mathrm{MR}$ \\
\hline Cluster-5 & 9 & $\begin{array}{l}\text { SVIN301, SVIN020, SVIN296, BR-8938-30-2-4-2-1, KARJAT-5, BRRI dhan28, } \\
\text { BRRI dhan29, BRRI dhan50, BRRI dhan63 }\end{array}$ & S \\
\hline Cluster-6 & 21 & $\begin{array}{l}\text { SVIN040, SVIN033, SVIN298, SVIN308, SVIN010, SVIN045, SVIN050, SVIN306, } \\
\text { SVIN029, SVIN296, SVIN001, SVIN041, SVIN024, SVIN047, SVIN299, SVIN306, } \\
\text { lRBB2, IRBB24, IRBB3, BR8995-2-5-5-2-1, BR(Bio) 9777-26-4-3 }\end{array}$ & S \\
\hline Cluster-7 & 4 & SVIN311, SVIN026, SVIN038, 1RBB10 & $\mathrm{MR}+\mathrm{S}$ \\
\hline Cluster-8 & 5 & SVIN017, SVIN316, SVIN307, SVIN018, SVIN318 & $\mathrm{R}+\mathrm{MR}$ \\
\hline Cluster-9 & 2 & BRRI dhan29-SC3-28-16-10-6-HR6(com)-HR1(GAZ)-P11(Hbj), IR99285-1-1-1-P2 & S \\
\hline Cluster-10 & 3 & SVIN301, SVIN037, SVIN321 & S \\
\hline Cluster-11 & 2 & 1RBB5, 1RBB64 & S \\
\hline Cluster-12 & 2 & IR99056-B-B-15, BR9207-45-2-2 & $\mathrm{S}$ \\
\hline Cluster-13 & 1 & SVIN020 & $\mathrm{S}$ \\
\hline Cluster-14 & 1 & SVIN046 & MR \\
\hline Cluster-15 & 1 & SVIN305 & $\mathrm{S}$ \\
\hline Cluster-16 & 1 & BR8862-29-1-5-1-3 & $\mathrm{S}$ \\
\hline
\end{tabular}

Note: R-Resistant, MR-Moderately resistant, S-Susceptible.

Table 5. Cluster wise mean of respective characters.

\begin{tabular}{llllllllllll}
\hline Cluster & PHT & NTH $^{-1}$ & ETH $^{-1}$ & DF & DM & PL & TNSP-1 & FSP-1 & UFSP-1 & TGW & YH $^{-1}$ \\
\hline Cluster-1 & 85.76 & 21.05 & 19.52 & 117.00 & 147.00 & 24.94 & 81.14 & 62.00 & 19.14 & 20.86 & 25.12 \\
Cluster-2 & 85.47 & 22.51 & 20.53 & 115.17 & 145.17 & 24.07 & 82.42 & 66.58 & 15.21 & 21.88 & 30.02 \\
Cluster-3 & 70.33 & 31.50 & 30.33 & 117.33 & 147.33 & 22.67 & 76.67 & 66.33 & 10.33 & 20.00 & 40.40 \\
Cluster-4 & 76.71 & 22.92 & 20.63 & 104.25 & 134.25 & 23.48 & 75.00 & 59.75 & 15.25 & 20.13 & 24.53 \\
Cluster-5 & 88.78 & 15.00 & 13.33 & 106.00 & 136.00 & 24.84 & 78.78 & 67.89 & 10.89 & 21.00 & 19.10 \\
Cluster-6 & 77.80 & 22.44 & 20.86 & 105.05 & 135.05 & 23.00 & 88.67 & 64.71 & 22.48 & 21.67 & 29.24 \\
Cluster-7 & 79.96 & 32.63 & 29.42 & 106.25 & 136.25 & 26.45 & 63.00 & 51.75 & 11.25 & 23.25 & 35.87 \\
Cluster-8 & 81.13 & 28.33 & 26.07 & 112.40 & 142.40 & 22.48 & 112.40 & 85.20 & 27.20 & 22.80 & 50.88 \\
Cluster-9 & 74.50 & 14.33 & 12.83 & 112.00 & 142.00 & 25.10 & 127.50 & 91.00 & 36.50 & 19.50 & 22.44 \\
Cluster-10 & 73.67 & 27.22 & 25.22 & 107.00 & 137.00 & 24.50 & 132.00 & 74.00 & 26.00 & 24.00 & 44.33 \\
Cluster-11 & 69.50 & 30.42 & 29.58 & 118.00 & 148.00 & 20.00 & 72.50 & 58.00 & 14.50 & 24.00 & 41.21 \\
Cluster-12 & 101.33 & 25.33 & 23.83 & 117.00 & 147.00 & 24.80 & 111.00 & 82.50 & 28.50 & 29.00 & 59.22 \\
Cluster-13 & 88.67 & 32.00 & 29.00 & 103.00 & 133.00 & 27.20 & 123.00 & 101.00 & 22.00 & 21.00 & 61.51 \\
\hline
\end{tabular}


Table 5. Continued.

\begin{tabular}{llllllllllll}
\hline Cluster & PHT & NTH $^{-1}$ & ETH $^{-1}$ & DF & DM & PL & TNSP-1 & FSP-1 & UFSP-1 & TGW & YH $^{-1}$ \\
\hline Cluster-14 & 102.67 & 19.67 & 17.33 & 118.00 & 148.00 & 23.60 & 100.00 & 77.00 & 23.00 & 20.00 & 26.69 \\
Cluster-15 & 88.67 & 19.33 & 14.00 & 112.00 & 142.00 & 25.00 & 80.00 & 64.00 & 16.00 & 19.00 & 17.02 \\
Cluster-16 & 71.20 & 14.33 & 8.67 & 112.00 & 142.00 & 27.00 & 132.00 & 106.00 & 26.00 & 18.00 & 16.54 \\
\hline
\end{tabular}

Note: PHT-Plant height, $\mathrm{NTH}^{-1}$ - Number of tiller per hill, $\mathrm{ETH}^{-1}$ - Effective tiller per hill, DF-Days to flowering, DM- Days to maturity, PL-Panicle length, TNSP-1-Total number of spikelet per panicle, FSP-1_Number of filled spikelet per panicle, UFSP-1-Number of unfilled spikelet per panicle, TGW-1000 grain weight, $\mathrm{YH}^{-1}$-Yield per hill.

\section{Principal component analysis (PCA)}

Correlation matrix of the samples were used to compute the principal components and the first component had the maximum variance. However, the PCA typically supported the cluster analysis. Some of the genotypes did not actually follow the clustering pattern in PCA and they grouped with another cluster. The first four principal components of PCA explained about $70.99 \%$ of overall divergence for all quantitative characters. From the eigenvectors study, it was found that $23.33 \%$, $19.81 \%, 17.59 \%$ and $10.26 \%$ variation could be revealed by the first four principal components (Table 6 and Fig. 1). Caldo et al. (1996) reported $67 \%$ of the total divergence of quantitative characters from 10 principal components while Lasalita-Zapico et al. (2010) reported $82.7 \%$ of total variation from 32 rice accesions.

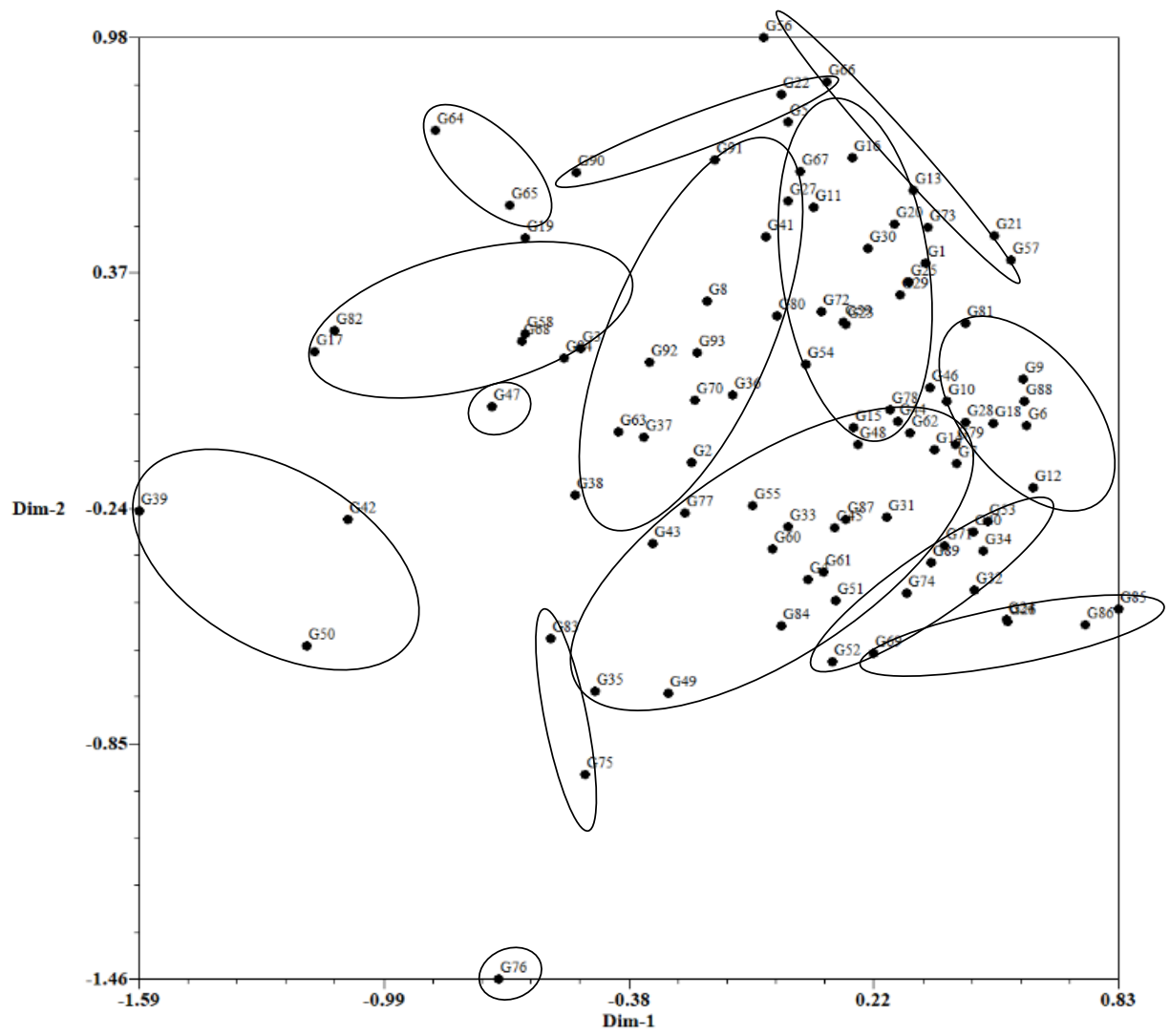

Fig. 1. Two-dimensional plot of principal component analysis portrayed the relationships of 94 genotypes by utilizing the data of 11 morphological characters. 
Table 6. Eigenvectors and eigen values of the first four principal components.

\begin{tabular}{lcccc}
\hline \multirow{2}{*}{ Variable } & \multicolumn{4}{c}{ Principal component } \\
\cline { 2 - 4 } Eigen value & PC1 & PC2 & PC3 & PC4 \\
Percent & 2.566 & 2.179 & 1.936 & 1.129 \\
Cumulative & 23.329 & 19.811 & 17.596 & 10.261 \\
PHT & 23.329 & 43.141 & 60.737 & 70.998 \\
NTH-1 & 0.226 & 0.283 & 0.182 & 0.515 \\
ETH- & -0.333 & 0.624 & -0.625 & -0.193 \\
DF & -0.340 & 0.647 & -0.634 & -0.104 \\
DM & -0.346 & 0.618 & 0.686 & -0.051 \\
PL & -0.346 & 0.618 & -0.051 \\
NSP-1 & 0.005 & -0.263 & 0.686 & -0.686 \\
FGP-1 & -0.866 & -0.413 & 0.312 & -0.032 \\
UFGP-1 & -0.780 & -0.317 & 0.028 & -0.024 \\
TGW & -0.504 & -0.339 & 0.140 & -0.027 \\
YH-1 & -0.642 & 0.035 & -0.193 & 0.376 \\
\hline NOte: & -0.151 & -0.267 & -0.089 & 0.442 \\
\hline
\end{tabular}

Note: PHT-Plant height, NTH ${ }^{-1}$ - Number of tiller per hill, ETH ${ }^{-1}$ - Effective tiller per hill, DF-Days to flowering, DM- Days to maturity, PL-Panicle length, TNSP-1-Total number of spikelet per panicle, FSP-1-Number of filled spikelet per panicle, UFSP-1-Number of unfilled spikelet per panicle, TGW-1000 grain weight, $\mathrm{YH}^{-1}$-Yield per hill.

PC1-Principal component-1, PC2-Principal component-2, PC3- Principal component-3. PC4- Principal component-4

\section{Principal coordinate analysis (PCoA)}

PCoA described the spatial distribution of the studied genotypes based on morphological traits. Two-dimensional graph of PCoA demonstrated that the genotypes BR8862-29-1-5-1-3 (G76), SVIN301 (G39), SVIN321 (G50), BR9207-45-2-2 (G82), SVIN018 (G17), 1RBB5 (G64), SVIN038 (G56), BRRI dhan28 (G85) and BRRI dhan29 (G86) were placed in distant position from the centroid and remaining genotypes situated at near to the centroid (Fig. 2). Results of the PCoA plot described that the genotypes which were situated in distant position from the central point were more diverse and genotypes near to the central point were less diverse. Strong heterosis is expected to be found by crossing between the parents having low similarity (Abubakar et al., 2011; Nihad et al., 2021).

\section{CONCLUSION}

In this study 94 genotypes were screened for disease reaction and morphological diversity. Out of 94 genotypes, 12 showed resistant reaction, 13 showed moderately resistant reaction and rest of the genotypes showed susceptible reaction. Yield hill ${ }^{-1}$ had high and significant positive correlation with the number of tiller hill ${ }^{-1}$, number of effective tiller hill $^{-1}$, total number of spikelets panicle ${ }^{-1}$, number of filled grain panicle ${ }^{-1}$, number of unfilled spikelet panicle ${ }^{-1}\left(0.239^{*}\right)$ and 1000 grain weight hill $^{-1}$. Moreover, based on 11 morphological characters, 94 rice genotypes were clustered into sixteen major groups and it indicates the presence of diversity among the genotypes. However, the PCA and PCoA mostly confirmed the cluster analysis. The first four principal components explained around $70.99 \%$ of total divergence for all quantitative 


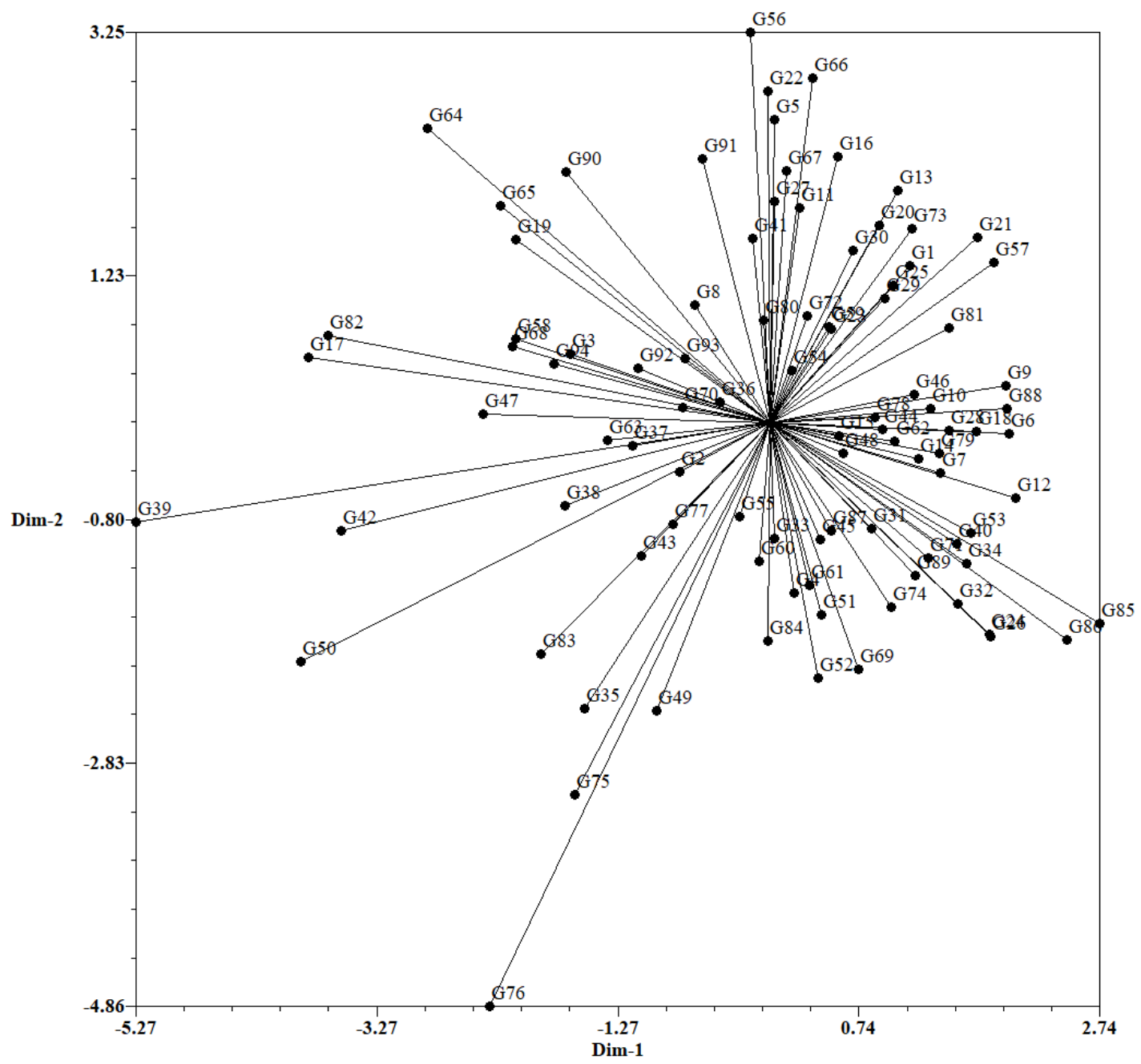

Fig. 2. Two-dimensional plot of principal coordinate analysis depicted the relationships of 94 rice genotypes by using the data of 11 morphological characters.

characters. However, based on disease reaction and genetic diversity analysis crossing could be done between genotype of two distant clusters, resistant genotypes such as SVIN317, SVIN017, SVIN316, SVIN313, SVIN315， SVIN314， SVIN038， SVIN307, SVIN302, SVIN304 with the susceptible lines or variety more specifically with BRRI dhan28, BRRI dhan29, BRRI dhan50, BRRI dhan58, BRRI dhan63, BRRI dhan74, BRRI dhan 81 and BRRI dhan 84 to develop bacterial blight resistant variety.

\section{AUTHORS' CONTRIBUTION}

SAIN: Conceptualization, data curation, formal analysis, investigation, methodology, resources, software, validation, writing original draft, writing - review and editing. AA: Conceptualization, methodology, data curation. MMR: Methodology, investigation. MAIH: Formal analysis. MAIK: Formal analysis, visualization. MAL: Conceptualization, resources, funding acquisition, supervision, writing - review and 
editing. All authors read and approved the final manuscript.

\section{ACKNOWLEDGEMENT}

Authors are highly grateful to Plant Pathology Division for providing the opportunity to conduct this experiment. Authors are also thankful to BRRI authority for providing the fund to do the experiment.

\section{DECLARATION OF INTERESTS}

The authors declare that they have no known competing financial interests or personal relationships that could have appeared to influence the work reported in this paper.

\section{FUNDING}

\section{Authority of Bangladesh Rice Research} Institute (BRRI) provided the funding through Head, Plant Pathology Division.

\section{REFERENCES}

Abubakar, B Y, R Wusirika, S Mua'zu, A U Khan, and A K Adamu. 2011. Detection of genetic variability using random amplified polymorphic DNA markers in some accessions of Moringa oleifera Lam. from northern Nigeria. International Journal of Botany, 7 (3): 237-242.

Ahmadikhah, A, S Nasrollanejad, and O Alishah. 2008. Quantitative studies for investigating variation and its effect on heterosis of rice. International Journal of Plant Production, 2(4): 297-308.

Caldo, R, L Sebastian and J Hernandez. 1996. Morphologybased genetic diversity analysis of ancestral lines of Philippine rice cultivars. Philippine Journal of Crop Science. 21(3): 82-96.

Chen, X, S Wang and Q Zhang. 2002. New gene for bacterial blight resistance in rice, Xa $25(\mathrm{t})$, was identified from Minghui 63, an elite restorer line. Phytopathology. 92: 750-754.

Goto, M. 1992. Fundamentals of bacterial plant pathology. San Diego. California USA: Academic Press. pp. 342.

IRRI. 2013. Standard Evaluation System for Rice (SES) (5th edition). Los Banos. Philippines: International Rice Research Institute (IRRI).

Islam, A B M M, J R Rahman, S A I Nihad, R Akter, H A Dilzahan, M Z Islam, M R Bhuiyan, M H Kabir, M M Rashid, M R Islam, M A Latif and M A I Khan. 2017.
Evaluation of indigenous rice germplasm for identification of durable bacterial blight (Xanthomonas oryzae pv. oryzae) resistance sources in Bangladesh. The Experiment, 43(3): 2495-2515.

Juroszek, P and A Von Tiedemann. 2011. Potential strategies and future requirements for plant disease management under a changing climate. Plant Pathology, 60:100-112. https://doi.org/10.1111/j.1365-3059.2010.02410.x

Kabir, M S, M U Salam, A Chowdhury, N M F Rahman, K M Iftekharuddaula, M S Rahman, M H Rashid, S S Dipti, A Islam, M A Latif, A K M S Islam, M M Hossain, B Nessa, T H Ansari, M A Ali and J K Biswas. 2015. Rice Vision for Bangladesh: 2050 and Beyond. Bangladesh Rice Journal, 19(2): 1-18.

Khush, G S, D J Mackill and G S Sidhu. 1989. Breeding of rice for resistance to bacterial blight. In: IRRI (ed.). Bacterial blight of rice. 207-217. IRRI, Manila, Phillipines.

Lasalita-Zapico, F C, J A Namocatcat, and J L CariñoTurner. 2010. Genetic diversity analysis of traditional upland rice cultivars in Kihan, Malapatan, Sarangani Province, Philippines using morphometric markers. Philippine Journal of Science, 139(2): 177-180

Latif, M A, M M Rahman, M E Ali. 2013. Inheritance studies of SSR and ISSR molecular markers and phylogenetic relationship of rice genotypes resistant to tungro virus. Comptes Rendus Biologies,336: 125133. https:// doi.org/10.1016/j.crvi.2012.12.002

Li, R, M Li, U Ashraf, S Liu and J Zhang. 2019. Exploring the relationships between yield and yield-related traits for rice varieties released in china from 1978 to 2017. Frontier in Plant Science, 10: 1-12. https://doi.org/10.3389/fpls.2019.00543

Mazid, M S, M Y Rafii, M M Hanafi, H A Rahim, M Shabanimofrad, and M A Latif. 2013. Agromorphological characterization and assessment of variability, heritability, genetic advance and divergence in bacterial blight resistant rice genotypes. South African Journal of Botany, 86:15-22.

Melchinger, A E. 1993. Use of RFLP markers for analysis of genetic relationship among breeding materials and prediction of hybrid performance. In: D R Buxton, $\mathrm{R}$ Shibles, R A Forsberg, B L Blad, K H Asay, G M Paulson and R F Wilson (Eds.), International Crop Science I, pp. 621-628, CSSA, Madison, WI.

Mizukami, T and S Wakimoto. 1969. Epidemiology and control of bacterial leaf blight of rice. Annual Review of Phytopathology, 7:51-72. https://doi. org/10.1146/ annurev.py.07.090169.000411 
Mizukami, T. 1956. Studies on the bacterial leaf blight of rice plant on the entrance and multiplying portion of the pathogen upon the rice plant leaves. Agriculture Bulletin of Saga University. 4: 169-175.

Nihad, S A I, A C Manidas, K Hasan, M A I Hasan, O Honey, M A Latif. 2021. Genetic variability, heritability, genetic advance and phylogenetic relationship between rice tungro virus resistant and susceptible genotypes revealed by morphological traits and SSR markers. Current Plant Biology, 25, 100194, doi:10.1016/j.cpb.2020.100194.

Ou, S H. 1985. Rice Diseases (2nd Edition) Common Wealth Mycological Institute, Kew,Surrey.

Reddy, C R and S H Ou. 1976. Characterization of Xanthomonas oryzae (Uyeda et. Ishiyama) Dowson, the bacterial blight pathogen of rice. Annual Review of Phytopathology. 42: 124-130. https:// doi.org/10.3186/jjphytopath.42.124

Rohlf, F J. 1998. NTSYS-pc, numerical taxonomy and multivariate system. version 2.0. Exet Software, New York.

Singh, G P, M K Srivastava, R V Singh and R M Singh. 1997. Variation and qualitative losses caused by bacterial blight in different rice varieties. Indian Phytopathology, 30: 180-185.

Wakimoto, S. 1969. Bacterial leaf blight of rice and its control. Biological Agriculture \& Horticulture, 32: 1523 1525.

Watanabe, Y. 1975. Ecological studies, kresek phase of bacterial leaf blight of rice. Bull. Tokaikinki Agricultural experiment station, 28: 50-123.

Wennberg, A. 2014. Food and Agriculture Organization of the United Nations. Encyclopedia Toxicology, Third Edition. https://doi.org/10.1016/B978-0-12-3864543.00988-X

Xu, Q, W Chen, and Z Xu. 2015. Relationship between grain yield and quality in rice germplasms grown across different growing areas. Breeding Science, 65(3): 226-232.

Zayan, S A. 2018. Impact of climate change on plant diseases and IPM strategies. Arab Journal of Plant Protection, 1:1-11. https:/ / doi.org/10.22268/ajpp036.1.075079

Zhai, W X and L H Zhu. 1999. Rice bacterial blight resistance genes and their utilization in molecular breeding. Advanced Biotech. 19: 9-15. 